\title{
Online Self-regulation Questionnaire: Validity and Reliability Study of Turkish Translation*
}

\author{
Selcan KiLis ${ }^{\mathbf{a}^{* *}}$, Zahide YILDIRIM ${ }^{\mathrm{b}}$ \\ ${ }^{a}$ Giresun Üniversitesi, Eğitim Fakültesi, Giresun/Türkiye \\ bOrta Doğu Teknik Üniversitesi, Bilgisayar ve Öğretim Teknolojileri Eğitimi, Ankara/Türkiye
}

\section{Article Info}

DOI: $10.14812 /$ cuefd.298791

Article history:

Received 18.03.2017

Revised $\quad 10.10 .2017$

Accepted 22.02.2018

Keywords:

Online self-regulation

questionnaire,

Validity,

Reliability,

Confirmatory factor analysis,

Self-regulation,

Online learning.

\begin{abstract}
This study aims to translate online self-regulated learning questionnaire (OLSQ) into Turkish and administer its validity and reliability issues. In the questionnaire, 24 items were translated into Turkish separately by nine experts, and then back-translation was conducted by two language experts. Pilot test was conducted with 321 students enrolled in fully online associate degree programs in a well-known public university in Adana, Turkey. In terms of validity issue, confirmatory factor analysis indicated that Turkish OLSQ was valid with acceptable worth of fit values. Regarding with reliability, Cronbach's alpha values indicating internal consistency varied between .67 and .87 for three sub-factors, and .95 for the whole instrument which yields high reliability. Therefore, Turkish OLSQ could be used to measure learners' self-regulated skills in any kind of online learning settings since it provided its validity and reliability issues and fits with the original version.
\end{abstract}

\section{Çevrimiçi Öz-düzenleme Ölçeğinin Türkçe 'ye Uyarlanması: Geçerlik ve Güvenirlik Çalışması*}

\begin{tabular}{|c|c|}
\hline \multicolumn{2}{|c|}{ Makale Bilgisi } \\
\hline \multicolumn{2}{|c|}{ DOI: $10.14812 /$ cuefd.298791 } \\
\hline \multicolumn{2}{|c|}{ Makale Geçmişi: } \\
\hline Geliş & 18.03.2017 \\
\hline Düzeltme & 10.10.2017 \\
\hline Kabul & 22.02 .2018 \\
\hline \multicolumn{2}{|c|}{ Anahtar Kelimeler: } \\
\hline \multicolumn{2}{|c|}{$\begin{array}{l}\text { Çevrimiçi öz-düzenle } \\
\text { Gecerlik }\end{array}$} \\
\hline Geçerlik, & \\
\hline Güvenirlik, & Doğrulayıcı faktör analizi, \\
\hline \multicolumn{2}{|c|}{ Öz-düzenleyici öğrenme, } \\
\hline \multicolumn{2}{|c|}{ Çevrimiçi öğrenme. } \\
\hline
\end{tabular}

\section{Öz}

Bu çalışmanın amacı, çevrimiçi öz-düzenleme ölçeğinin Türkçe geçerlik ve güvenirlik analizinin yapılmasıdır. Ölçekte yer alan 24 soru dokuz uzman tarafından ayrı ayrı çevrilmiştir. Geri çevirme işlemi iki dil uzmanı tarafından yapılmıştır. Ölçekte yer alan soruların çevrilme işi tamamlandıktan sonra Adana'da tamamen uzaktan eğitim alan 321 ön lisans öğrencisinden veri toplanmıştır. Doğrulayııı faktör analizine göre uyum indeksleri kabul edilir uygun seviyede bulunmuş ve Türkçe' ye çevrilen ölçeğin geçerli olduğu görülmüştür. Ölçeğin güvenirlik için hesaplanan iç tutarlılık katsayılarını gösteren Cronbach alfa katsayıları 0,67 ve 0,87 arasında değişiklik göstermekte, ölçeğin tamamı için 0,95 bulunmuştur; dolayısıyla yüksek güvenirlik değerleri göstermiştir. Dolayısıyla, geçerlik ve güvenirliği sağlanan çevrimiçi öz-düzenleme ölçeğinin Türkçe sürümünün orijinal sürümü ile uyumlu olduğu görüldüğü için e-öğrenme ortamlarında öğrencilerin öz-düzenleme becerilerini ölçmek için kullanılabilir.

\footnotetext{
* This study was conducted in the scope of doctoral dissertation of the first author.

*** Corresponding Author: k1selcan@gmail.com
} 


\section{Introduction}

Self-regulation is, as lexical meaning defined by English \& English (1958) as the control of one's efforts based on motives about his/her specified and subsequent goal or ideal. It simply means selfcontrol or self-discipline. In the sense of learning science, self-regulation defined as is the composition of "self-generated thought, feelings and actions that are planned and cyclically adapted to the attainment of personal goals" (Zimmerman, 2000, p.14). Zimmerman (2000) defined three phases of self-regulation; namely, forethought, performance or volitional control and self-reflection. It is the interaction of personal, behavioral and environmental triadic processes in the sense of social-cognitive theory (Bandura, 1986). In general, educational and developmental psychologies define it as various ways to monitor, control and regulate the learning (Schunk \& Zimmerman, 1994; Zimmerman, 1986; Zimmerman \& Schunk, 1989). Self-regulated learners, according to Zimmerman (1989) are "metacognitively, motivationally, and behaviorally active participants in their own learning process" ( $p$. 329). They direct their own efforts and learning to acquire knowledge and skills without depending on any member of instruction.

The cyclical structure of self-regulation, as illustrated in Figure 1 encompasses three cyclical stages; namely, forethought (before), performance or volitional control (during), and self-reflection (after) phases (Zimmerman, Boekarts, Pintrich, \& Zeidner, 2000). Forethought includes two main sub-process, namely, task analysis including goal setting and strategic planning and self-motivational beliefs including self-efficacy, outcome expectations, intrinsic interest or value and goal orientation (Sandars \& Cleary, 2011; Zimmerman, et al., 2000). This stage is like a preparatory phase and as Zimmerman (2000) argued, underscores the proactive essence of self-regulatory skills. Moreover, they provide the impetus to put forth the necessary effort for the learners to engage in the self-regulation process (Sandars, et al., 2011). Performance or volitional control encompasses two sub-process; the first is self-control including selfinstruction, imagery, attention focusing and task strategies and the second is self-observation including self-recording and self-experimentation. Finally, self-reflection contains two sub-process again, the first is self-judgement including self-evaluation and causal attribution whilst the second is self-reaction including self-satisfaction or affect and adaptive-defensive tasks.

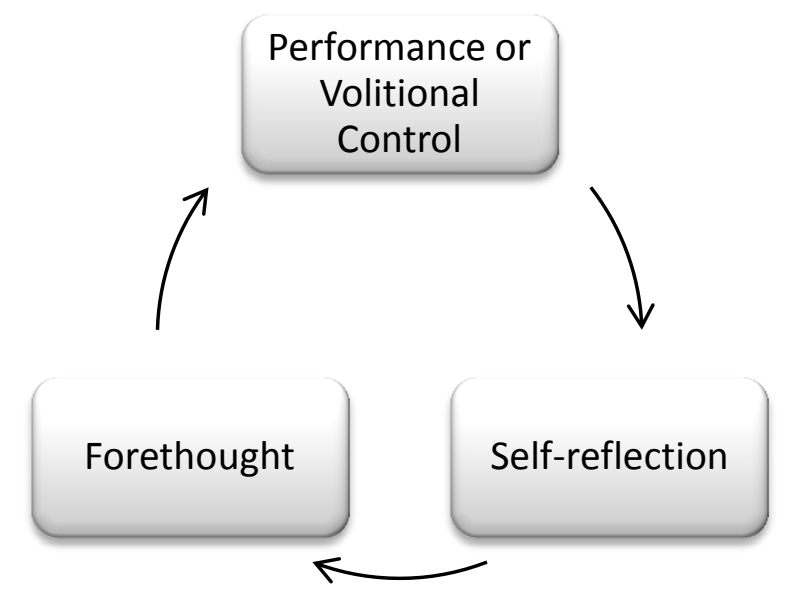

Figure 1. Cyclical phases of self-regulation. Reprinted from Self-regulated Learning: from Teaching to Self-reflective Practice. (p.3), by D. H. Schunk and B. J. Zimmerman (Eds.), 1998, New York: Guilford Press. Copyright 1998 by Guilford Press. Reprinted with permission. In Schunk \& Zimmerman, B. J.

(2000). A Social Cognitive Perspective. Handbook of self-regulation, 13, p.16) 
Self-regulation is a critical factor to be successful and to accomplish desired goals (Shea, Hayes, Smith, Vickers, Bidjerano, Gozza-Cohen, Jian, Pickett, Wilde, Tseng, 2013) in any learning environment. It is more important in online learning settings since the nature of online learning environment is characterized by autonomy and real instructors are absent (Artino \& Stephens, 2009; Barnard, Lan, To, Paton, \& Lai, 2009; Dabbagh \& Kitsantas, 2004, Schunk \& Zimmerman, 1998).

In order to measure students' self-regulation in online learning setting, Online Self-Regulated Learning Questionnaire (OSLQ) was developed by Lan, Bremer, Stevens and Mullen (2004) with 5-point Likert type response format. It includes 86-item yielding in six sub-scale constructs: environment structuring (ES); goal setting (GS); time management (TM); help seeking (HS); task strategies (TS); and self-evaluation (SE). The higher scores on this instrument indicate better self-regulation in online learning by students.

It was shortened later including 24-item by Barnard, Paton and Lan (2008) with 204 students enrolled in online learning. In short form, it includes 24 -item yielding in six sub-scales and in the form of 5 -point Likert type response format. The subscales namely factors and the number of items reflecting these subscales are ES with 5 items, GS with 4 items, TM with 4 items, HS with 3 items, TS with 4 items and SE with 4 items. According to Zimmerman (1998), among six sub-scales of OSLQ, ES involves "selecting or creating effective settings for learning", GS signifies "specifying intended actions or outcomes", TS denotes "analyzing tasks and identifying specific, advantageous methods for learning", TM refers to "estimating and budgeting use of time", HS means "choosing specific models, teachers, or books to assist oneself to learn", and finally SE signifies "setting standards and using them for selfjudgment" (pp.76-79).

The short from of OSLQ has also been validated and found reliable (Barnard, et al., 2009). The validity was checked with confirmatory factor analysis and fit indices found acceptable. The results indicate evidence toward construct validity of the instrument for the students both in blended and online learning settings. The reliability was provided with checking internal consistency values. Cronbach's Alpha value which indicates internal consistency value of the scores was found to be 0.93 for the whole instrument. Cronbach alpha values by subscale ranged from .67 to .90 in blended learning and .87 to .96 in online learning.

The questionnaire has been already translated into Turkish in earlier studies by Uzun, Ünal and Yamaç (2013) and Yetik (2011). However, Uzun, Ünal and Yamaç (2013) in their study did not check the reliability and validity. They just translated the instrument and then directly used without any confirmation and validation. Yetik (2011) translated the instrument in her thesis study, but she conducted the validity process with the students in face-to-face education having prior online learning experience. However, checking the instrument items based on past experiences of the students can affect the results. Students, during responding to the instrument items can have different opinions or behaviors based on prior experience since they were in fact educated in face-to-face education and their experience was just based on the past. For this reason, the short form of OSLQ was translated into Turkish in the scope of this study with appropriate target sample, settings, and context; students are enrolled in full online learning program in order to have a valid and reliable version after taking permission via email from the owners. Therefore, this study aims to translate short form of OSLQ into Turkish and administer its validity and reliability issues.

\section{Method}

This empirical study aims to translate online self-regulation questionnaire into Turkish in addition to administering its validity and reliability tests. The details about applied methodology are explained in continuing part. 


\section{Participants}

An empirical study requires adequate sample size to conduct the statistical analysis and obtain reliable results (Pearson \& Mundfrom, 2010). Validity and reliability issues of translated version of online self-regulation questionnaire into Turkish, after translation process was completed were checked and provided with 321 students enrolled in vocational school of higher education in a well-known public university in Adana, Turkey. Of 321 students, 181 were female, 140 were male. Their age changed to 1848 , the majority of them $(38 \%, n=121)$ were at the ages of $18-22$, followed by $23-27(24 \%, n=78), 28-32$ $(19 \%, n=62)$, then $33-37(13 \%, n=43), 38-42(4 \%, n=12)$, and $43-48(2 \%, n 5)$. Their disciplines included Pediatric Development (44\%, $n=140)$, Electronic Communication Technology $(30 \%, n=96)$, Computer Technology and Programming $(18 \%, n=59)$, and Accounting and Tax Practicing $(8 \%, n=26)$. All these departments were fully online degree programs. They only take their final exams face-to-face. Corresponding to their grade level, the majority of the students were sophomores $(44 \%, n=140)$, followed by freshman $(18 \%, n=59)$, juniors $(30 \%, n=96)$, and seniors $(8 \%, n=26)$.

\section{Data Collection Procedure}

The questionnaire was applied in the format of paper-based before the final exam to the students that are educated in the type of online education. The data was collected at spring semester of 20142015 academic year. The questionnaire was distributed to in total of 444 students, the missing cases (123) were excluded from the data and in the analysis 321 students' responses were included.

\section{Translation Procedure}

The aim of this study is to adapt online self-regulation questionnaire into Turkish and administer its validity and reliability features. Translation and back-translation of 24 items were done. The items were firstly translated by one of the authors in the first phase and also by five more experts (two of them got PhD degree, while three are PhD candidates in Instructional Technology) separately and they are experienced in the field and know English well. Then, translated versions were compared and the instrument was revised based on the translation comparison in the second phase. After, first revised version was sent to two experts who are more experienced and took PhD degree again in the field of Instructional Technology. In the same way, they translated the instrument into Turkish separately. Translations were compared and required changes (second revision) were done by the authors in third phase. In fourth stage, translated version of the instrument was sent for final revisions and checking content, equality between the items in two languages, grammar and meaning to another expert who is working as a professor in the field and also works in cognitive and metacognitive constructs for many years. Based on her feedback, the instrument was taken its final form in the next step after required changes were made. After translation process was completed, it was sent to two language experts who work in Modern Languages, specifically Department of English Language. Two language experts made back-translation. The original and back-translated versions of the instrument were compared to be sure that the translation was made correctly and appropriately. The diagram which shows the procedure of translation process is illustrated in Figure 2.

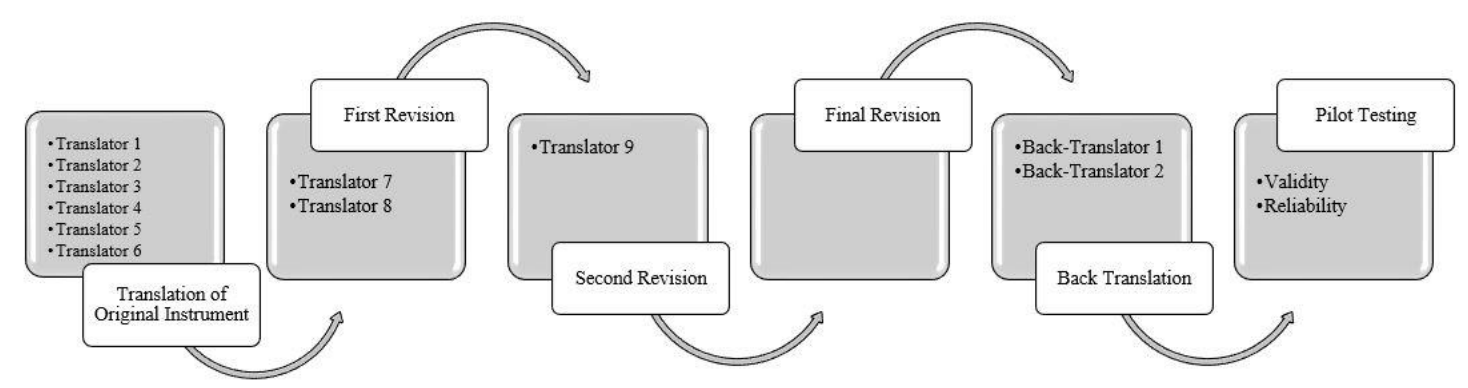

Figure 2. Translation procedure 


\section{Data Analysis}

The data were entered to SPSS program and controlled two times. The data were imported to IBM SPSS AMOS version 21.0 for confirmatory factor analysis (CFA) which rests on a solid theoretical or empirical base, how many factors there are and whether they are correlated or not are already known based on empirical base (Stevens, 2009). The aim of CFA is to confirm a hypothesized factor structure with the data by forcing items to load only on a specific factor. Likert type items of the questionnaire are defined as scale on the SPSS for the analysis. During the CFA, maximum likelihood estimates was applied.

The required assumptions of CFA were checked before conducting the analysis. Considering adequate sample size, minimum sample size should be more than 200 according to Guilford (1954), 5 subjects per item, namely 120 for Hair et al. (2010) and 10 subjects per item, namely 240 for MacCallaum and Widaman (1999) since the instrument includes 24-items. According to the statements of aforementioned authors, sample size $(n=321)$ in this study was adequate for the analysis. The outliers were checked via descriptive statistics and boxplots in SPSS and eliminated from the data. The missing data were checked and all of them were deleted from the data since the sample size is already more than the required minimum number of adequate sample size. Univariate and multivariate normality were checked in AMOS using skewness and kurtosis values and all of them laid in -2 and +2 , and the data were provided normality assumptions (George \& Mallery, 2010).

\section{Results}

\section{Validity Results}

In the analysis of CFA about the estimated model of translated instrument, goodness of fit statistics including $\chi 2 / \mathrm{df}$ (Chi-Square/Degree of Freedom), Root Mean Square Error of Approximation (RMSEA), Standardized Root Mean Square Residual (SRMR), Goodness of Fit Index (GFI), Adjusted Goodness of Fit Index (AGFI), Comparative Fit Index (CFI) and Tucker-Lewis Index (TLI) used. RMSEA is a "population based index that relies on the non-central $\chi 2$ distribution, which is the distribution of the fitting function when the fit of the model is not perfect. RMSEA is an error of approximation index because it assesses the extent to which a model fits reasonably well in the population and relatively insensitive to sample size. RMSEA values of 0 indicate perfect fit and values very close to suggest good model fit" (Brown, 2015, pp.71-72). As the author states, RMR reflect the average discrepancy between observed covariance and predicted covariance. However, since RMR value is affected by the metric of the input variables; it is difficult to interpret and for this reason SRMR is generally preferred as Brown (2015) contended. SRMR indicates the average discrepancy between the correlations observed in the input matrix and the correlations predicted by the model. Its values can vary between 0 and 1 , with 0 indicates a perfect fit. GFI index is "roughly analogous to the multiple R2 value in multiple regression in that it represents the overall amount of the covariation among the observed variables that can be accounted for by the hypothesized model" (Stevens, 2009). Therefore, the larger GFI value represents better model fit (Ong \& Van Dulmen, 2007). AGFI adjusts the GFI for the number of degrees of freedom. The values close to 1 indicates better model. CFI that is also referred to as incremental fit indices evaluates the fit of a user-specified solution in relation to a more restricted, nested baseline model (Brown, 2015). TLI known as the non-normed fit index has features that compensate for the effect of model complexity like RMSEA as Brown (2015) defined. It includes "a penalty function for adding freely estimated parameters that do not markedly improve the fit of the model" (p.72). NFI "represents the increment in fit obtained by using the hypothesized model relative to the fit of the null model. Values range from zero to one, with higher values indicative of a greater improvement in fit" (p.72). The goodness of fit statistics of the translated instrument was presented in Table 1. 
Table 1.

CFA Indices of Turkish OSLQ.

\begin{tabular}{lllll}
\hline $\begin{array}{l}\text { Goodness of Fit } \\
\text { Statistics }\end{array}$ & Perfect & Acceptable & $\begin{array}{l}\text { Original } \\
\text { Version }\end{array}$ & $\begin{array}{l}\text { Translated } \\
\text { Version }\end{array}$ \\
\hline$\chi^{2} /$ df & $\leq 3$ & $\leq 5$ & 2.77 & 2.45 \\
RMSEA & $\leq .05$ & $\leq .08$ & .06 & .06 \\
RMR & $\leq .05$ & $\leq .08$ & -- & .08 \\
SRMR & $\leq .05$ & $\leq .08$ & -- & .06 \\
TLI & $\geq .95$ & $\geq .90$ & .94 & .89 \\
CFI & $\geq .95$ & $\geq .90$ & .93 & .90 \\
GFI & $\geq .95$ & $\geq .90$ & -- & .86 \\
AGFI & $\geq .90$ & $\geq .85$ & -- & .84 \\
$\mathrm{NFI}$ & $\geq .95$ & $\geq .90$ & -- & .80 \\
\hline$* p<.01$ & & & &
\end{tabular}

According to the findings, with a $\chi 2 / \mathrm{df}$ ratio value of 2.45 , the translated instrument was acceptable. The worth of fit values was found to be $\chi 2 / \mathrm{df}=2.45, \mathrm{RMSEA}=.06, \mathrm{RMR}=.08, \mathrm{SRMR}=.06, \mathrm{TLI}=.89, \mathrm{CFI}=$ $.90, \mathrm{GFI}=.86, \mathrm{AGFI}=.84$ and $\mathrm{NFI}=.80$. According to these values, it can be said that GFI, AGFI, CFI, TLI and NFI observable fit values were slightly lower than acceptable value, but very close to good fit values while RMSEA, SRMR, and RMR fit values indicated an acceptable and good fit (Table 1). In other words, the obtained model indicated that the factors were confirmed by the data (Çokluk et al., 2010; Sümer, 2000; Tabachnick \& Fidell, 2013). In addition, the item-factor structure of translated version of selfregulation instrument is indicated in Figure 3. According to the item-factor structure, all indicators of the observed variables GS, ES, TS, TM, HS, and SE appear to be almost about equal weights based on their standard regression weights (factor loadings) that can be interpreted as the correlation between the observed variable and the corresponding common factor. The path diagram also shows the squared multiple correlation coefficients (R2) that describes the amount of variance the common factor accounts for in the observed variables. For instance, the highest amount of variance explained is by ES that explains about the $66 \%$ of the variance in ES3. The lowest amount of variance explained is by TS that explains $30 \%$ of the variance in TS2. Moreover, the correlations between the common factors are also displayed in the path diagram. The highest correlation is between HS and SE with the value of .99 and the lowest correlation is with the value of .50 between ES and TM. 


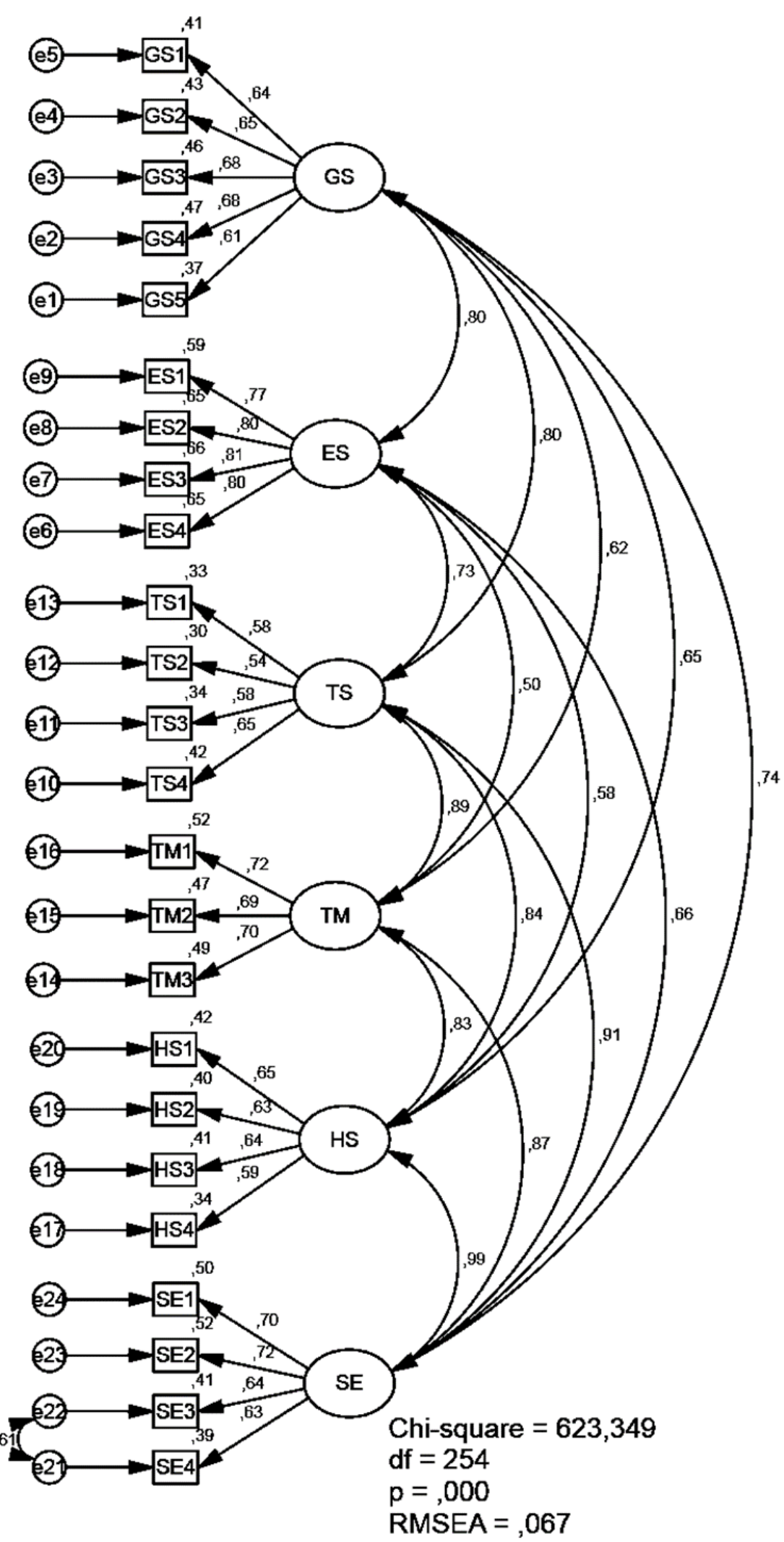

Figure 3. Item-factor structure of Turkish OSLQ 


\section{Reliability Results}

Considering the reliability, internal consistency was assessed via Cronbach alpha values. The results are illustrated in Table 2.

\section{Table 2.}

Reliability Statistics of Six Factors of Turkish OSLQ.

\begin{tabular}{ll}
\hline Factor & Cronbach's Alpha \\
\hline Self-regulation & .95 \\
GS & .79 \\
ES & .87 \\
TS & .67 \\
TM & .75 \\
HS & .71 \\
SE & .81 \\
\hline${ }^{*} p<.01$ &
\end{tabular}

The coefficient alpha values of the factors of the instrument were found in the range of .67 and .87 and .95 for the whole. All the factors have alpha values higher than .70 except one; however, its value is very close to .70. Therefore, all the factors showed acceptable internal consistency values (Hair, et al. 2010) and therefore Turkish version of OSLQ found reliable.

\section{Discussion \& Conclusion}

In this research, online self-regulation questionnaire was translated into Turkish and administered validity and reliability issues with the data collected from 321 students enrolled in fully online associate degree programs in a well-known public university in Adana, Turkey.

Confirmatory factor analysis indicated that fit values were found as $\chi 2 / d f=2.45, R M S E A=.06, R M R$ $=.08, \mathrm{SRMR}=.06, \mathrm{TLI}=.89, \mathrm{GFI}=.86, \mathrm{AGFI}=.84, \mathrm{CFI}=.90$, and NFI = .80; therefore it is inferred that although GFI observable fit value was slightly lower than acceptable value, RMSEA, SRMR and AGFI fit values indicate an acceptable fit and other observable fit values indicate a perfect fit. According to these obtained fit indices, GFI, AGFI, CFI, TLI and NFI observable fit values were slightly lower than acceptable value, but very close to good fit values while RMSEA, SRMR, and RMR fit values indicated an acceptable and good fit.

Regarding reliability, internal consistency values measured via Cronbach alpha .95 for the whole instrument, and ranged between .67 and .87 for its six sub-factors. All the factors have Cronbach alpha values higher than .70 except one which is very close to .70 and therefore, all the sub-factors yielded acceptable values (Hair, et al. 2010) regarding internal consistency and found acceptable.

It is indicated in the literature that, self-regulation is a critical factor to accomplish desired goals (Shea, et al., 2013) in any learning environment. It is more important in online learning settings since the nature of online learning environment is characterized by autonomy, and there is a distance between the learner and the instructor (Artino \& Stephens, 2009; Barnard, Lan, To, Paton, \& Lai, 2009; Dabbagh \& Kitsantas, 2004, Schunk \& Zimmerman, 1998). In such learning environments, lack of self-regulation may result with drop out from the online programs. Therefore, it is important to determine students' online self-regulated learning and then, provide self-regularity support for the students if necessary. Since the most universities in Turkey have distance education centers and online education programs, it is more important to monitor online students' self-regulated learning ever before. In that respect, the Online Self-regulated Learning Questionnaire in Turkish will provide educators support in this respect. 


\section{Türkçe Sürümü}

\section{Giriş}

Öz-düzenleme, sözlük anlamı olarak English ve English (1958) tarafından kişinin belli bir amacı ya da idealini gerçekleştirmek için güdülenmesine bağlı olarak gösterdiği çabasını kontrol etmesi olarak tanımlanır. Öz-düzenleme en sade haliyle öz-kontrol veya öz-disiplin olarak da adlandırılmaktadır. Eğitim-öğretim sürecinde öz-düzenleme, kişinin bireysel amaçlarını gerçekleştirmek için periyodik olarak yaptığı ve planladığı kendiliğinden olan duygu, düşünce ve hareketleri olarak tanımlanmaktadır (Zimmerman, 2000). Zimmerman, öz-düzenleme becerilerini sağduyu, performans veya irade ile ilgili kontrol ve öz-yansıtma (öz-düşünüm) olmak üzere üç aşamalı olarak açıklamıştır (Şekil 1). Bandura (1986) ise öz-düzenlemeyi sosyal-bilişsel kurama göre bireysel, davranışsal ve çevresel olmak üzere üçlü bir süreç olarak açıklar. Genel olarak, eğitim ve gelişim psikolojisinde öz-düzenleme becerileri öğrenmeyi gözlemleme, kontrol etme ve düzenleme (yönetme) olarak tanımlanır (Schunk \& Zimmerman, 1994; Zimmerman, 1986; Zimmerman \& Schunk, 1989). Öz-düzenleme becerileri gelişmiş olan öğrenciler, üst bilişsel, güdüsel ve davranışsal olarak kendi öğrenme süreçlerinde aktif katılımcı olan öğrencilerdir (Zimmerman, 1989). Bu öğrenciler, öz-düzenleme becerileri yüksek düzeyde ve gelişmiş olduğu için, herhangi bir bilgiyi öğrenmek ya da beceriyi kazanmak için herhangi bir yönergeye gerek kalmaksızın öğrenme süreci boyunca kendi çabalarını yönetebilirler.

Öz-düzenleme herhangi bir öğrenme ortamı sürecinde belirlenen amaçları gerçekleştirebilmek ve başarılı olmak için önemli bir rol oynar (Shea, vd. 2013). Özellikle uzaktan eğitim ve çevrimiçi öğrenme ortamlarında öz-düzenleme daha da önemlidir. Çünkü bu tür öğrenme ortamlarında geleneksel sınıf ortamlarında olduğu gibi gerçek zamanlı öğretmenler yoktur ve öğrenme ortamı ve süreci daha özerktir (Artino \& Stephens, 2009; Barnard, Lan, To, Paton, \& Lai, 2009; Dabbagh \& Kitsantas, 2004, Schunk \& Zimmerman, 1998). Bu yüzden özellikle uzaktan eğitim ve çevrimiçi öğrenme ortamlarında özdüzenleme becerileri çok daha önemlidir.

Çevrimiçi öğrenme ortamlarında öğrencilerin öz-düzenleme becerilerini ölçmek amacıyla Lan, Bremer, Stevens ve Mullen (2004) 86 sorudan oluşan 5'li Likert yapısında bir ölçme aracı geliştirmiştir. $\mathrm{Bu}$ ölçme aracına göre, yüksek puan öğrencilerin öz-düzenleme becerilerinin yüksek seviyede gelişmiş olduğunu göstermektedir. Bu ölçme aracı daha sonra Barnard, Paton ve Lan (2008) tarafından kısaltılarak 24 soruya düşürülmüştür. Ölçeğin kısa formunda 24 soru bulunmaktadır. Soru türü, ölçeğin özgün formunda olduğu gibi 5'li Likert türündedir. Yine aynı şekilde öz-düzenleme becerilerinin altı alt faktörü kısa formda bulunmaktadır. Ölçeğin kısa formunun geçerlik ve güvenirlik testi 24 öğrenciden veri toplanarak yapılmıştır (Barnard, Lan, To, Paton, \& Lai, 2009). Analiz sonucuna göre, ölçeğin kısa formu orijinali gibi geçerli ve güvenilir bulunmuştur. Daha sonra birçok benzer çalışma kullanılmıştır.

Öz-düzenleme ölçeğinin kısa formu Türkçe alan yazında Uzun, Ünal ve Yamaç (2003) tarafından Türkçe' ye çevrilmiştir. Ancak, araştırmacılar sadece ölçek sorularını Türkçe 'ye çevirmiş ve geçerlik ve güvenirlik testi yapmadan direkt olarak kullanmıştır. Dolayısı ile bahsi geçen bu çeviri işlemi istatistiksel olarak ve bilimsel olarak eksik olduğu için, kabul edilebilir ve uygulanabilir değildir. Benzer şekilde, bu ölçek daha önce Yetik tarafından 2011 yılında yine Türkçe' ye çevrilmiştir. Ancak çeviri işleminin ölçeğin orijinali ile uyumlu olup olmadığını ve yapılan çevirinin geçerli ve güvenilir olup olmadığı test ederken geleneksel sınıf ortamındaki öğrencilerle çalışılmıştır. Ancak bahsedilen ölçme aracı, çevrimiçi öğrenme ortamlarındaki öğrencilerin öz-düzenleme becerilerini ölçmeye yönelik olduğundan ölçek soruları çevrimiçi öğrenme ortamına yönelik becerileri saptamaya yöneliktir. Dolayısı ile ölçeğin geçerlik ve güvenirlik çalışması ölçeğin amacına uygun olan bir örneklem ile yapılmadığından, yapılan çeviri ve test işlemleri, istatistiksel ve bilimsel olarak uygun değildir. Bu yüzden, bu çalışmada çevrimiçi öz-düzenleme ölçme aracı Türkçe' ye yeniden çevrilerek geçerlik ve güvenirlik testleri ölçme aracını amacına paralel uygun örneklem ile test edilecektir. 


\section{Yöntem}

Bu çalışmanın amacı çevrimiçi öz-düzenleme ölçeğinin Türkçe 'ye çevrilerek geçerlik ve güvenirlik testinin yapılmasıdır. Çevrimiçi öz-düzenleme ölçeğinde bulunan 24 soru alanında uzman 9 araştırmacı tarafından ayrı ayrı Türkçe' ye çevrilmiştir. Daha sonra Türkçe 'ye çevrilen sorular iki dil uzmanı tarafından ayrı ayrı tekrar İngilizce' ye çevrilerek ölçeğin orijinali ile uyumlu olup olmadığı karşılaştırılmıştır. Ölçeğin Türkçe' ye çevrilme süreci ve yapılan işlemler Şekil 2'de gösterilmiştir. Gerekli son düzenlemeler yapıldıktan sonra ölçek, geçerlik ve güvenirlik testi için Türkiye'nin Adana ilinde tanınmış bir devlet üniversitesinde uzaktan eğitimle eğitim-öğretim yapılan ön lisans programlarına kayıtlı öğrencilere uygulanmıştır. Toplam 444 öğrencinin katıldığı ölçek, öğrencilerin final sınavından hemen önce yüz yüze uygulanmıştır. Eksik veriler (123) çıkarıldıktan sonra, toplam 321 öğrencinin verisi analiz sürecine dâhil edilmiştir. Geçerlik testi için doğrulayıcı faktör analizi, güvenirlik testi için iç tutarlılık katsayılarını hesaplayan Cronbach alfa değerleri hesaplanmıştır. Analizler, IBM SPSS programı 21.sürümü ile yapılmıştır. Analiz öncesi gerekli varsayımlar test edilerek sağlanmıştır.

Doğrulayıc faktör analizi için gerekli varsayımlardan ilki, yeterli örneklem büyüklüğüdür. Alan yazında yeterli örneklem büyüklüğü konusunda Guilford (1954) 200'den fazla olmalı, Hair ve arkadaşları (2010) her soru için en az beş katılımcı olmalı, MAcCallaum ve Widaman (1999) ise her soru için en az 10 kişi olmalı diye belirtmiştir. Öz-düzenleme ölçeği toplam 24 soru içerdiği için, yeterli örneklem büyüklüğü farklı yazarların belirttiği ölçülere göre, sırasıyla 200, 120 ve 240 olmalıdır. Diğer varsayımlara göre eksik veriler ve aykırı değerler çıkarıldıktan sonar, analiz sürecinde toplam 321 katılımcının verisi ile çalışıldığı için; yeterli örneklem büyüklüğü şartı da sağlanmıştır. Aykırı değerler IBM SPSS programı kullanılarak tanımlayıcı istatistikler ve kutu diyagramı ile test edilmiştir. Eksik veriler kontrol edilerek toplam veriden çıkarılmıştır. Tek değişkenli ve çok değişkenli normal dağılım testleri IBM AMOS programında çarpıklık ve basıklık testleri ile kontrol edilmiş ve verinin normal dağılım testleri sağlanmıştır. Analiz sonuçları bulgular bölümünde verilmiştir.

\section{Bulgular}

Geçerlik testi için yapılan doğrulayıcı faktör analizine göre, çevrimiçi öz-düzenleme ölçeğinin 6 faktörlü yapısının uyum istatistikleri $\chi 2 / \mathrm{df}=2.45, \mathrm{p}<0,01, \mathrm{RMSEA}=.06, \mathrm{RMR}=.08, \mathrm{SRMR}=.06, \mathrm{TLI}=$ $.89, \mathrm{CFI}=.90, \mathrm{GFI}=.86, \mathrm{AGFI}=.84$ ve NFI $=.80$ olarak bulunmuştur (Tablo 1 ). Türkçe ölçme aracının madde-faktör yapısı Şekil 3'te verilmiştir. Doğrulayıcı faktör analizi sonuçlarına göre uyum istatistikleri değerleri yeterli ve kabul edilir derecede bulunduğu için, ölçeğin geçerliği sağlanmıştır. Güvenirlik testi için hesaplanan Cronbach alfa iç tutarlılık katsayısı ölçeğin tamamı için 0,95 bulunmuştur. Faktörlerin Cronbach alfa iç tutarlılık katsayıları 0,67 ve 0,87 arasında değişiklik göstermiştir (Tablo 2). Buna göre, ölçeğin tamamı ve alt faktörleri için ayrı ayrı hesaplanan Cronbach alfa katsayıları değerlerine göre; Türkçe' ye çevrilen çevrimiçi öz-düzenleme ölçeği yüksek seviyede güvenilir bulunmuştur.

\section{Tartışma ve Sonuç}

Türkçe' ye çevrilen çevrimiçi öz-düzenleme ölçeğinin geçerlik testine göre, Türkçe ölçme aracı kabul edilir düzeyde uygun ve geçerli bulunmuştur. Ayrıca güvenirlik testine göre, Türkçe ölçme aracının güvenirliğinin yüksek seviyede olduğu görülmüştür. Dolayısıyla, Türkçe' ye çevrilerek geçerlik ve güvenirlik testleri yapılan ve uygun bulunan Türkçe çevrimiçi öz-düzenleme ölçeğinin, bahsi geçen ölçeğin orijinali ile uyumlu olduğu görülmüştür. Ayrıca Türkçe çevrimiçi öz-düzenleme ölçeğinin uzaktan eğitim ve çevrimiçi eğitim-öğretim ortamlarında öğrencilerin öz-düzenleme becerilerini ölçmek için kullanılması istatistiksel olarak uygun bulunmuştur. Türkçe' ye çevrilerek geçerlik ve güvenirlik testleri yapılan ve uygun bulunan bu ölçme aracı, bundan sonraki araştırmalarda kullanılabilir. Ayrıca, eeğitmenler kendi öğrencilerinin öz-düzenleme becerilerini ölçmek için bu ölçme aracını tekrar bir teste ya da çeviriye gerek kalmadan olduğu gibi kullanabilirler. Daha önce Türkçe uyarlaması iki kere yapılmasına rağmen, bilimsel olarak geçerli ve uygun olmadığı için bu çalışma kapsamında Türkçe' ye çevrilerek bilimsel ve istatistiksel olarak uygun yöntemlerle geçerlik ve güvenirlik testleri yapılan çevrimiçi öz-düzenleme ölçeği, Türkçe alan yazına da katkı yapmıştır. 


\section{References}

Artino, A. R., \& Stephens, J. M. (2009). Academic motivation and self-regulation: A comparative analysis of undergraduate and graduate students learning online. The Internet and Higher Education, 12(3), 146-151.

Bandura, A. (1986). Social foundations of thought and action: A social cognitive theory. Englewood Cliffs, NJ: Prentice-Hall.

Barnard, L., Lan, W. Y., To, Y. M., Paton, V. O., \& Lai, S. L. (2009). Measuring self-regulation in online and blended learning environments. The Internet and Higher Education, 12(1), 1-6.

Barnard, L., Paton, V., \& Lan, W. (2008). Online self-regulatory learning behaviors as a mediator in the relationship between online course perceptions with achievement. The International Review of Research in Open and Distributed Learning, 9(2), 1-11.

Brown, T. A. (2015). Confirmatory factor analysis for applied research. Guilford Publications.

Çokluk, Ö., Şekercioğlu, G. \& Büyüköztürk, Ş. (2010). Sosyal bilimler için çok değişkenli istatistik. Ankara, Pegem Yayıncılık.

Dabbagh, N., \& Kitsantas, A. (2004). Supporting self-regulation in student-centered Web-based learning environments. International Journal on E-Learning, 3(1), 40-47.

English, H.B., \& English, A.C. (1958). A comprehensive dictionary of psychological and psychoanalytical terms. NewYork: McKay.

George, D. \& Mallery, M. (2010). SPSS for windows step by step: A simple study guide and reference, 17.0 update (10/e ed.) Boston: Pearson.

Guilford, J. P. (1954). Psychometric methods (2th Ed). New York: McGraw-Hill.

Hair, J. F., Black, W.C., Tatham, R. L., \& Anderson, R. E. (2010). Multivariate data analysis. Upper Saddle River, NJ: Prentice Hall.

Lan, W. Y., Bremer, R., Stevens, T., \& Mullen, G. (2004). Self-regulated learning in the online environment. Paper presented at the 2004 annual meeting American Educational Research Association, April 7-8, San Diego.

MacCallum, R. C. \& Widaman K. F. (1999). Sample size in factor analysis. Psychological Methods. 4(1), 84-99.

Ong, A. D., \& Van Dulmen, M. H. (Eds.). (2007). Oxford handbook of methods in positive psychology (pp. 111-125). New York: Oxford University Press.

Pearson, R. H., \& Mundform, D. J. (2010). Recommended sample size for conducting exploratory factor analysis on dichotomous data. Journal of Modern Applied Statistical Methods, 9(2), 359-368.

Sandars, J., \& Cleary, T. J. (2011). Self-regulation theory: Applications to medical education: AMEE Guide No. 58. Medical teacher, 33(11), 875-886.

Schunk, D. H, \& Zimmerman, B. J. (Eds.). (1998). Self-regulated learning: From teaching to self-reflective practice. New York: The Guilford Press.

Schunk, D. H., \& Zimmerman, B. J. (1994). Self-regulation of learning and performance: Issues and educational applications. Hillsdale, NJ: Lawrence Erlbaum Associates

Shea, P., Hayes, S., Smith, S. U., Vickers, J., Bidjerano, T., Gozza-Cohen, M., Jian, S. B., Pickett, A. M., Wilde, J. \& Tseng, C. H. (2013). Online learner self-regulation: Learning presence viewed through quantitative content-and social network analysis. The International Review of Research in Open and Distributed Learning, 14(3), 427-461.

Stevens, J. (2009). Applied multivariate statistics for the social sciences $\left(5^{\text {th }}\right.$ Ed.). NJ: Lawrence Erlbaum Associates. 
Kilis ve Yıldırım - Çukurova Üniversitesi Eğitim Fakültesi Dergisi, 47(1), 2018, 233-245

Sümer, N. (2000). Yapısal eşitlik modelleri: Temel kavramlar ve örnek uygulamalar. Türk Psikoloji Yazıları, $3(6): 74-79$.

Tabachnick, B. G. \& Fidell, L. S. (2013). Using multivariate statistics (6th Ed). Needham Heights, MA: Allyn and Bacon.

Uzun, A. M., Ünal, E., \& Yamac, A. (2013). Service teachers' academic achievements in online distance education: The roles of online self-regulation and attitudes. Turkish Online Journal of Distance Education, 14(2), 131-140.

Yetik, S. S. (2011). Çevrimiçi öz düzenleyici öğrenme ortamında farklı denetim odaklarına göre sunulan metabilişsel rehberliğin öğretmen adaylarının öz düzenleme becerilerine ve öz yeterlik algılarına etkisi. Yayınlanmamış doktora tezi. Ankara Üniversitesi Eğitim Bilimleri Enstitüsü, Ankara.

Zimmerman, B. J. (1998). Academic studing and the development of personal skill: A self-regulatory perspective. Educational Psychologist, 33(2-3), 73-86.

Zimmerman, B. J. (2000). Attaining self-regulation: A social cognitive perspective. In M. Boekaerts, P. Pintrich, \& M. Zeidner (Eds.), Handbook of self-regulation, research, and applications (pp. 13-39). California, USA: Academic Press.

Zimmerman, B. J., \& Schunk, D. H. (1989). Self-regulated learning and academic achievement: Theory, research, and practice. New York: Springer-Verlag.

Zimmerman, B. J., Boekarts, M., Pintrich, P. R., \& Zeidner, M. (2000). A social cognitive perspective. Handbook of self-regulation, 13(1), 695-716. 


\section{Appendix}

\begin{tabular}{|c|c|c|c|c|c|}
\hline & 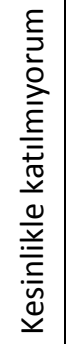 & 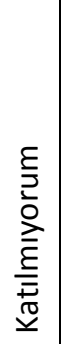 & 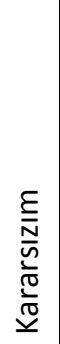 & 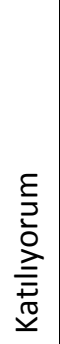 & 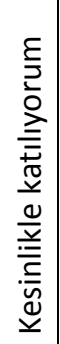 \\
\hline \multicolumn{6}{|l|}{ Hedef Belirleme } \\
\hline \multicolumn{6}{|l|}{ 1. Çevrimiçi derslerdeki ödevlerim için ölçütler belirlerim. } \\
\hline \multicolumn{6}{|l|}{$\begin{array}{l}\text { 2. Kısa-vadeli hedeflerin (günlük veya haftalık) yanı sıra uzun vadeli hedefler de (aylık } \\
\text { veya dönem/sömestr boyunca) belirlerim. }\end{array}$} \\
\hline \multicolumn{6}{|l|}{ 3. Çevrimiçi derslerdeki öğrenmem için ölçütlerimi yüksek tutarım. } \\
\hline \multicolumn{6}{|l|}{$\begin{array}{l}\text { 4. Çevrimiçi derslerde çalışma zamanımı ayarlamaya yardımcı olması için hedefler } \\
\text { belirlerim. }\end{array}$} \\
\hline \multicolumn{6}{|l|}{ 5. Çevrimiçi olmasından dolayı çalışmamın kalitesinden ödün vermem. } \\
\hline \multicolumn{6}{|l|}{ Çevre Düzenlenmesi } \\
\hline \multicolumn{6}{|l|}{ 6. Çalışma ortamımı fazla dikkat dağıtacak şeylerden uzak olacak şekilde seçerim. } \\
\hline \multicolumn{6}{|l|}{ 7. Ders çalışmak için rahat bir yer bulurum. } \\
\hline \multicolumn{6}{|l|}{ 8. Çevrimiçi dersler için en verimli çalışabileceğim yeri bilirim. } \\
\hline \multicolumn{6}{|l|}{ 9. Çevrim içi derslerime çalışmak için dikkat dağıtan şeylerin az olduğu zamanı seçerim. } \\
\hline \multicolumn{6}{|l|}{ Ders Çalışma Stratejileri } \\
\hline \multicolumn{6}{|l|}{$\begin{array}{l}\text { 10. Çevrimiçi dersler için daha ayrıntılı notlar tutmaya çalışırım, çünkü ders notları } \\
\text { çevrimiçi öğrenmede normal sınıftaki öğrenmeye göre daha önemlidir. }\end{array}$} \\
\hline \multicolumn{6}{|l|}{$\begin{array}{l}\text { 11. Dikkat dağıtan şeyleri önlemek için çevrimiçi gönderilen öğretim materyallerini } \\
\text { yüksek sesle okurum. }\end{array}$} \\
\hline \multicolumn{6}{|l|}{ 12. Sorularımı, çevrimiçi sohbet odasına ve tartışmaya katılmadan önce hazırlarım. } \\
\hline \multicolumn{6}{|l|}{$\begin{array}{l}\text { 13. Ders içeriğini iyice öğrenmek için çevrimiçi derslerde verilen problemlere ek olarak } \\
\text { ilave problemlere de çalışırım. }\end{array}$} \\
\hline \multicolumn{6}{|l|}{ Zaman Yönetimi } \\
\hline \multicolumn{6}{|l|}{$\begin{array}{l}\text { 14. Zaman alıcı olduğunu bildiğim için çevrimiçi derslerime çalışırken fazladan zaman } \\
\text { ayırırım. }\end{array}$} \\
\hline \multicolumn{6}{|l|}{$\begin{array}{l}\text { 15. Çevrim içi derslere çalışmak için her gün veya her hafta aynı zamanı ayarlamaya } \\
\text { çalışırım ve bu çizelgeyi uygularım. }\end{array}$} \\
\hline \multicolumn{6}{|l|}{$\begin{array}{l}\text { 16. Günlük derslere katılım zorunluluğumuz olmamasına rağmen, yine de çalışma } \\
\text { sürelerimi günlere eşit olarak bölmeye çalışıım. }\end{array}$} \\
\hline \multicolumn{6}{|l|}{ Yardım Isteği } \\
\hline \multicolumn{6}{|l|}{$\begin{array}{l}\text { 17. Ders içeriğine hâkim bilgili birini bulurum, böylece yardıma ihtiyacım olduğunda ona } \\
\text { danışabilirim. }\end{array}$} \\
\hline \multicolumn{6}{|l|}{$\begin{array}{l}\text { 18. Sorunlarımı sınıf arkadaşlarımla çevrimiçi olarak paylaşıım, böylece hangi } \\
\text { problemlerle uğraştığımızı ve onları nasıı çözeceğimizi biliriz. }\end{array}$} \\
\hline \multicolumn{6}{|l|}{ 19. Eğer gerekirse sınıf arkadaşlarımla yüz yüze görüşmeye çalışırım. } \\
\hline \multicolumn{6}{|l|}{ 20. Dersi veren öğretim elemanından e-posta yoluyla yardım almada ısrarcıyımdır. } \\
\hline \multicolumn{6}{|l|}{ Öz Değerlendirme } \\
\hline \multicolumn{6}{|l|}{ 21. Çevrimiçi derslerde ne öğrendiğimi anlamak için öğrendiklerimi özetlerim. } \\
\hline \multicolumn{6}{|l|}{ 22. Çevrimiçi bir derse çalışırken, ders içeriği ile ilgili kendime birçok soru sorarım. } \\
\hline \multicolumn{6}{|l|}{ 23. Çevrimiçi derslerde nasıl olduğumu anlamak için sınıf arkadaşlarımla konuşurum. } \\
\hline $\begin{array}{l}\text { 24. Sınıf arkadaşlarımın öğrendiğinden farklı ne öğrendiğimi anlamak için onlarla } \\
\text { konuşurum. }\end{array}$ & & & & & \\
\hline
\end{tabular}

